Jpn. J. Oral. Biol., $27:$ 1093-1100, 1985.

\title{
ラット咬筋における運動終板の分布
}

\author{
松本 林 ${ }^{* * *)}$ 桂茂*) \\ 徳島大学歯学部口腔解剖学第 1 講座*) (主任 : 桂 茂教授) \\ 徳島大学医学部第 1 解剖学講座**) (主任 : 山田正興教授)
}

〔受付 : 昭和60年 8 月 22 日]

\section{Distribution of motor endplates in rat masseter muscle}

\author{
Hayashi Matsumoto*)**) and Shigeru Katsura*) \\ Department of Oral Anatomy, School of Dentistry, Tokushima University, \\ Tokushima 770, Japan*) \\ (Chief: Prof. Shigeru Katsura) \\ Laboratory for Cytochemistry, Department of Anatomy, Tokushima University, \\ Tokushima, 770, Japan**)
}

(Chief: Prof. Masa-oki Yamada)

[Accepted for publication: August 22, 1985]

Key words : Motor endplate / acetylcholinesterase (Ach E)/ masseter muscle / rat

Abstract : The spatial distribution of motor endplates in rat masseter muscle was investigated histochemically by staining for acetylcholinesterase (Ach E) activity in serial frozen sections cut in coronal, horizontal and parasagittal planes. Motor endplates were found to be scattered in several regions of this muscle. These regions were identical with the muscular compartments in this muscle previously reported by us (Matsumoto, H. \& Katsura, S: Multiple compartmentalization in the fiber architecture of rat masseter muscle. Acta Anat. Nippon. $60: 90-98,1985)$. Several motor endplates were found in each region. All motor endplates were of the 'terminaisons en plaque' type. One motor endplate for each muscle fiber was situated in approximately the central one-third of the fiber and one motor nerve ending was found in each motor endplate.

\section{緒言}

骨格筋線維の運動終板の形態 (Coërs ${ }^{1}$; Cole $^{2}$; Couteaux $^{3,4)}$; Tiegs $^{51}$; Yamada ${ }^{6)}$ ) や筋線維上で の分布位置 (Barker, et al. ${ }^{7)}$; Bennett \& Pettigrew $^{8,9)}$; Christensen ${ }^{10)}$; Coërs ${ }^{1,11)}$; Couteaux $^{3,4)}$; Diamond \& Miledi' ${ }^{12)}$; Ginsborg \& Mackay ${ }^{13)}$ ；Kaczmarski ${ }^{14)}$ ) および支配神経の数 (Brown, et al. ${ }^{15)}$; Hess ${ }^{16)}$; Macky \& Peters ${ }^{17)}$; Pachter $^{18)}$ ) 等については多数の研究所見が報告 されている.しかし, 器官全体としての筋組織内 における運動終板の分布状態についての研究は少 なく, わずかにネコの腓腹筋の外側頭 と足底筋 徳島市藏本町三丁目（广 770）
(English \& Letbetter ${ }^{19)}$ ) や橈側 手根届筋（Galvas \& Gonyea $\left.{ }^{20 \prime}\right)$, 数種の哺乳類の外眼筋 ( $\mathrm{Ka}$ czmarski $^{14)}$; Mayr, et al. ${ }^{21)}$; Pachter $\left.{ }^{18)}\right)$, ラッ 卜の縫工筋, 薄筋, 殿筋, 外肛門括約筋 (Repciuc \& Timus $\left.^{22 \prime}\right)$ およびブタの咬筇 (Herring, et al. ${ }^{23 \prime}$ ) 等における報告に接するだけである。特にラット の咀嚼筋についての研究としては Karlsen ${ }^{24)}$ の報 告があげられるのに過ぎない。筋内における運動 終板の分布位置を知るためには，筋組織の筋線維 構築を検討しておく必要がある。さきに著者等 (Matsumoto \& Katsura ${ }^{251}$ ) はラット咬筋につい てこの点を研究し報告したので, 今回はアセチル コリンエステラーゼの組織化学的検出法である Beermann \& Cassens ${ }^{26)}$ の方法を活用して, ラ 
ットの咬筋における運動終板の筋内における分布 状態と単一筋線維上での存在部位を検討すること にした。

\section{材料および方法}

成熟雄ウィスター系ラット5 匹（150-470g）を エーテル麻酔下に殺し，左側の咬筋を採取した。 ついで，筋を液体窒素であらかじめ泠却しておい たイソペンタン中に投入して凍結固定し， $-20^{\circ} \mathrm{C}$ のクリオスタット (Bright Cryostat Model FS/ FAS, 5030 Microtome) 内で $30 \mu \mathrm{m}$ の連続切片を 作製した. 切断は Fig. 1 に示した方向に行った。 染色に先立って, Pearson \& Sabarra ${ }^{27)}$ の方法に 従って，あらかじめエチレンジァミン四酢酸 (EDTA)でコートしたスライドグラス上に切片を 貼布し，室温下で乾燥した後に，Beermann \& Cassens $^{26)}$ の方法に従って同一切片上でアセチル コリンエステラーゼ (Ach E) 染色と鍍銀とを行 った。一部の切片については筋線維の構築を知る ために H \& E 染色を行った。紡錘外筋線維上で の運動終板の 位置の 算定は, 切断方向, 切断さ
れた 組織切片の 外形, 切片の切断順位等による ことにした。下顎孔の下部に付着点を有する compartment No. 3 部域の笳 (Matsumoto \& Katsura ${ }^{25 \prime \prime)}$ )の採取には時間がかかったので，竻を あらかじめ $10 \%$ ホルマリン+ $1 \% \mathrm{CaCl}_{2}$ 溶液で固 定した後に上記の方法により運動終板の検出を行 った。本研究においては，Weijs ${ }^{28)} の$ 分類による浅 層筋と深層筋の紡錘外筋線維について 観察した。

\section{結果}

Beermann \& Cassens ${ }^{25)}$ の方法によると, 神経 笳接合部は濃褐色に, 軸索は黒色に, 筋線維は淡 黄色むしくは黄褐色に染色され，これらの識別は 容易であった。神経筋接合部は楕円形を呈する terminaison en plaque であり, その長軸は筋線維 の長軸に並行していた。また単一笳線維には 1 個 の運動終板が存在し，1個の運動終板には，1本 の運動神経終末しか見出すことができなかった (Fig. 2)。各運動終板の短軸方向に連結した線 (innervation band) は筋線維の長軸に対してほ ぼ直角であった。また，切断面上の運動終板は集

a
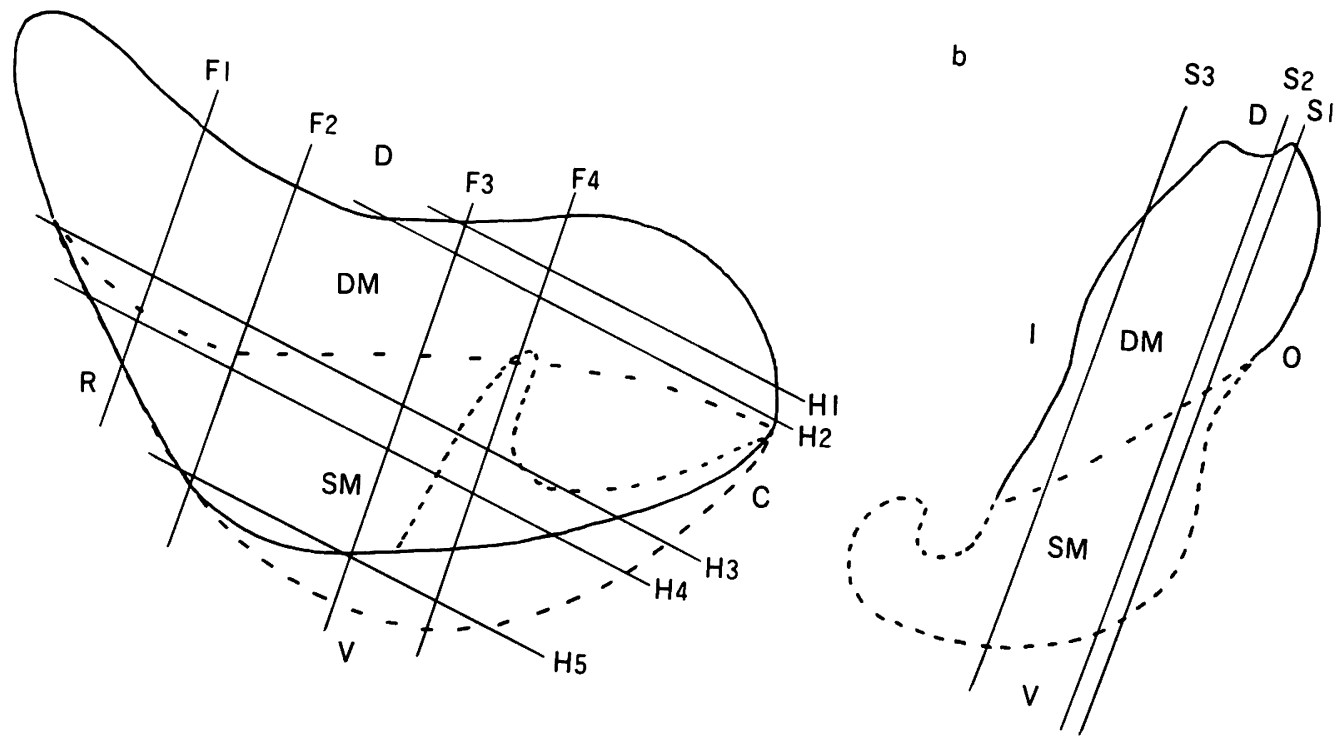

Fig. 1 Directions in which sections were cut. a ; lateral view of the left masseter muscle of rat ; b ; coronal view. Coronal cuts: F1, F2, F3 and F4 ; horizontal cuts: H1, H2, $\mathrm{H} 3, \mathrm{H} 4$ and $\mathrm{H} 5$; parasagittal cuts : S1, S2 and S3. SM ; superficial masseter; DM; deep masseter ; R ; rostral ; C ; caudal ; D ; dorsal ; V ; ventral ; I inner ; O ; outer. 


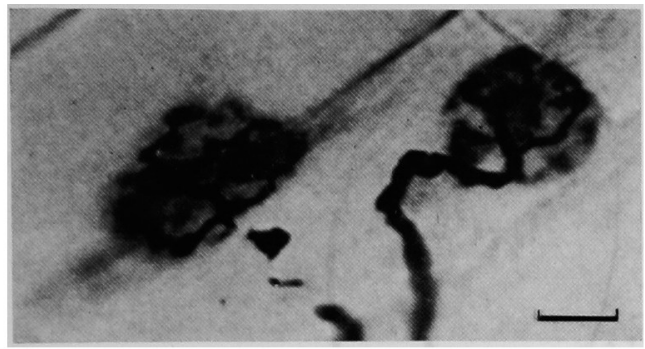

Fig. 2 Motor endplates in the rat masseter muscle stained with the method of Beermann \& Cassens (1976). Motor endplates are oval and their long axes are parallel to the long axes of the muscle fibers. Each muscle fiber has only one motor endplate. There is one motor nerve ending in each motor endplate. Bar $10 \mu \mathrm{m}$.

団をなして存在していたので，群として記載する ことにした。

I）浅層筇に打ける運動終板の分布パターン

a）前頭断面の所見：前頭断面の連続切片を吻 側から観察すると，Fig. 3b に示したように吻側 の腹側部の深部にまず運動終板の集団（A群）が 認められ，ついで中間部になると，背腹方向にほ ぼ直線状に走る帯状域に分布する集団（B1， B2 群）と腹側部で塊状の集合を示す集団（C 群）と が認められた (Fig. 3c)。また，尾部では，筋の 外表に近い部域で背腹方向に走る直線状の 帯状域 に分布する集団 (D群) が認められた（Fig. 3d)。

b) 水平断面の所見：連続切片を背側から腹 側へかけて観察すると, Figs. 4c, 4d and $4 \mathrm{e}$ に 示したように $a_{1}, a_{2}, a_{3}, a_{4}, b$ 群がほぼ直線状 に走る帯状域に分布していた。なお b 群の運動終 板は横断され， $\quad \mathrm{a}$ 群の 運動終板は縦断されてお り, 両群の笳線維の走行が異なることが知られ た。

c）準矢状断面の所見：連続切片を表層から深 層へかけて観察すると, Fig. 5a に示すように表 層では吻尾方向に走るほぼ直線状の帯状域に分布 する集団（I 群）と尾側背部で塊状の集合を示す 集団（II群）とが認められた。また深部では，吻 尾方向に配列する集団 (III群) とやや背腹方向に 配列する集団 (IV群) とが認められた (Fig. 5b)。 さらに深部の腹側では塊状の集合を示す集団（V
群）が見出された（Fig. 5c）。

II）深層笳における運動終板の分布パターン

a）前頭断面の所見：連続切片を吻側から尾側 へかけて観察すると，吻側では，Fig. 3a に示し たように内外方向にほぼ直線状に走る带状域に分 布する集団（E1，E2，E3 群）が認められ，中間 部から尾側にかけては, F, G, H 群 (Fig. 3b)， $\mathrm{I}, \mathrm{J}, \mathrm{K}$ 群 (Fig. 3c), L, M, N, O, P1, P2 群 (Fig. 3d) が認められた。

b) 水平断面の所見 : 連続切片を背側から腹側 一観察すると, 背側では, $c_{1}, d_{1}, e_{1}$ 群 (Fig. 4a), $\mathrm{c}_{2}, \mathrm{f}, \mathrm{g}, \mathrm{d}_{2}, \mathrm{~d}_{3}, \mathrm{e}_{2}, \mathrm{e}_{3}, \mathrm{e}_{4}$ 群 (Fig. 4b) が認められ, 中間部では, $\mathrm{h}, \mathrm{i}_{1}, \mathrm{~d}_{4}, \mathrm{~d}_{5}, \mathrm{j}_{1}, \mathrm{j}_{2}, \mathrm{e}_{5}, \mathrm{e}_{6}$ 群が認めら れた (Fig. 4c)。また腹側では, $\mathrm{k}_{1}, \mathrm{k}_{2}, \mathrm{i}_{2}, \mathrm{j}_{3}, \mathrm{j}_{4}$ 群 が見出された (Fig. 4d)。

c）準矢状断面の所見：連続切片を浅層から深 層へかけて観察すると, 浅部から中間部にかけて, VI, VII, VIII, LI 群 (Fig. 5a), X, XI, XII, XIII, XIV 群 (Fig. 5b) が認められた。また深部では, XV, XVI, XVII, XVIII, XIX, XX, XXI, XIII, XXIII, XXIV 群 (Fig. 5c) が認められた。

\section{考察}

骨格筋の運動神経終末の形態については， terminaison en plaque や terminaison en ligne $と$ terminaison en grappe 型等が報告されている $\left(\mathrm{Cole}^{2 \prime}\right)$ 。著者等の本研究所見からすると, ラッ トの咬笳の 紡鍾外管線維は terminaison en plaque に属することが明らかになった。この点では Cole ${ }^{2)}$ がラットの腸脛骨筋と椎骨下筋で terminaison en plaque 型の運動神経終末だけを認めて いる所見と一致していた。

また，骨格筋線維は筋線維上での運動終板の分 布位置によって 2 型に大別されている。すなわち， タイプ1線維は運動終板が筋線維の特定の 部域に 限局しているものであり，大部分の成熟哺乳類の 紡鍾外筋線維 (Brown, et $a l{ }^{15)}$; Christensen ${ }^{10)}$; Coërs $^{1,11)}$; Couteaux ${ }^{3,4)}$; English \& Letbetter ${ }^{19)}$; Galvas \& Gonyea ${ }^{201}$; Herring, et al..$^{23)}$ ) やへビ の肋間筋 (Mackay \& Peter ${ }^{17)}$ ) でみられているも のであり，タイプ 2 はびまん性に散在するもので 

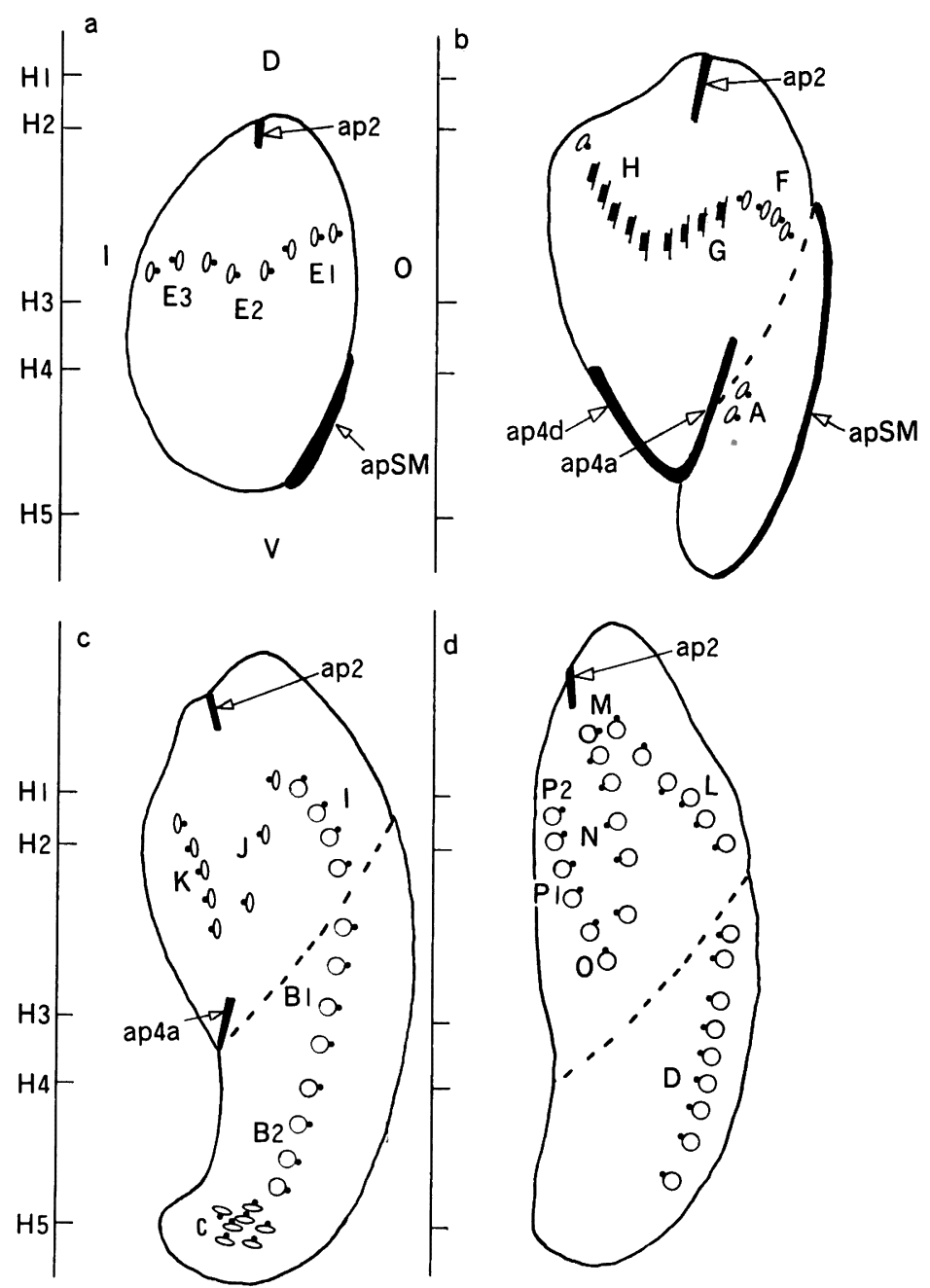

Fig. 3a-d Distribution of motor endplates in the rat masseter. Coronal sections of the masseter viewed from the anterior surface. Sections at a; level $\mathrm{Fl} ; \mathrm{b}$; level F2; c; level F3; d; level F4. 00; motor endplate cut obliquely; $\mathrm{O}^{\circ}:$ motor endplate cut transversely; ; motor endplate cut longitudinally; ap; aponeurosis.

末成熟の紡鍾外筋線維 (Bennett \& Pettigrew ${ }^{8,9)}$; Brown, et al. ${ }^{151}$; Diamond \& Miledi' ${ }^{12)}$ ) や紡 錘内筋線維 (Barker, et al. ${ }^{7)}$; Coërs ${ }^{1,111}$ ) およ びマウスやラットの外眼筋 (Kaczmarski ${ }^{14)}$; Pachter $\left.{ }^{18)}\right)$ やヒト・サル・ネコ等の縫工笳と薄 筋 $\left(\right.$ Christensen ${ }^{101} ;$ Coërs ${ }^{1,11}$; Couteaux $\left.{ }^{41}\right)$ 等 でみられている。また，筋組織はその内部に存在 する運動終板の種類によって 3 型に分類されてい
る(Ginsborg \& Mackay $^{13)}$; Hess $^{16)}$; Pachter $^{18)}$ )。 すなわちタイプIは前述のタイプ1線維のみから 構成されているものであり，タイプIはタイプ 2 のみから， タイプIIIはタイプ1とタイプ 2 線維の 混在によって構成されているものである。

本研究における前頭・水平・準矢状断面上で見 出された各群の相互関係を比較検討すると，（A， $b, I V),\left(B 1, a_{1}, I\right),\left(B 2, a_{3}\right.$, III $),\left(D, a_{2}, I I\right)$, 


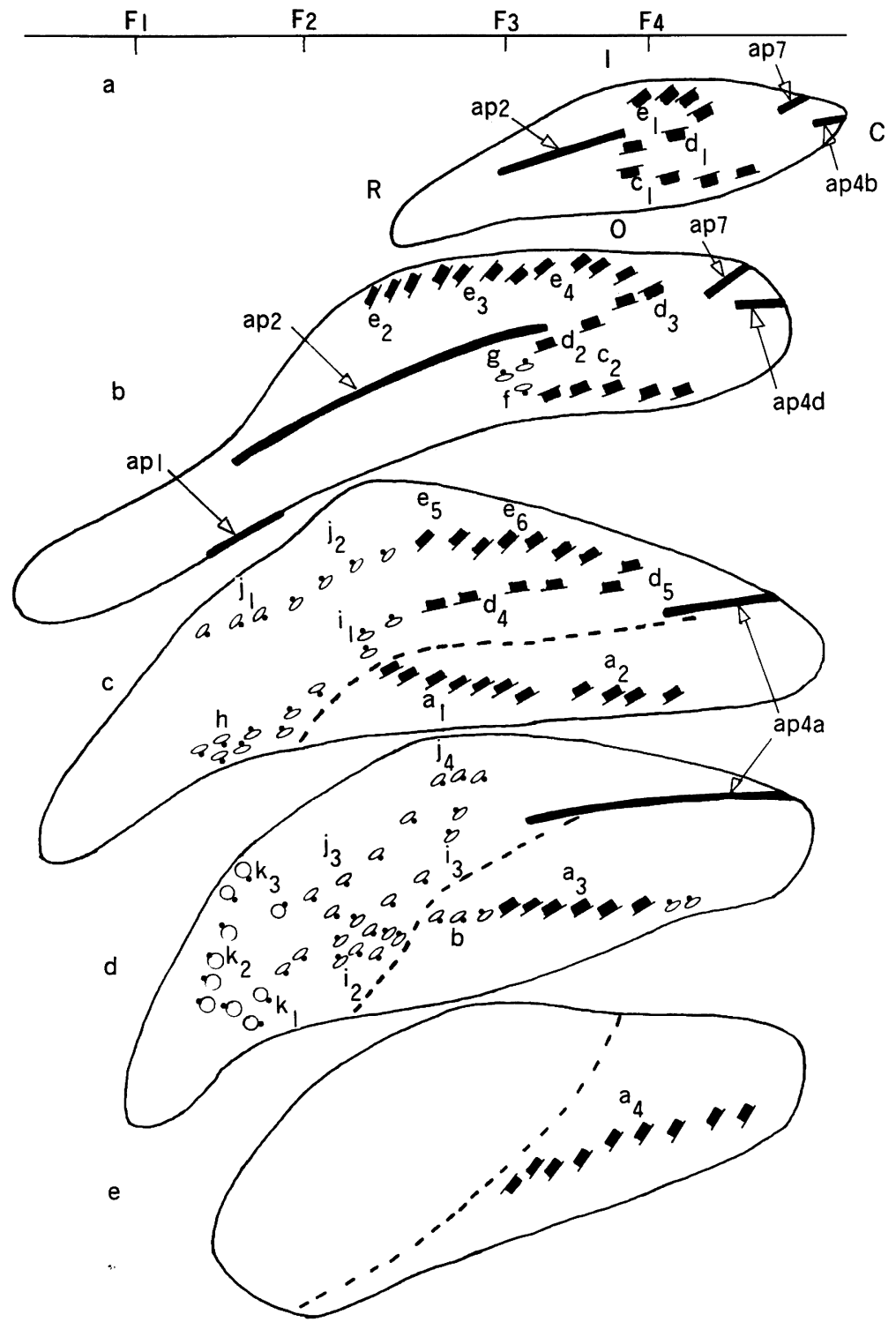

Fig. 4a-e. Distribution of motor endplates in the rat masseter. Horizontal sections of the masseter viewed from the dorsal surface. Sections at a ; level $\mathrm{H} 1$; b ; level $\mathrm{H} 2$; c ; level $\mathrm{H} 3$; d level $\mathrm{H} 4$; e ; level $\mathrm{H} 5$.

$\left(\mathrm{C}, \mathbf{a}_{4}, \mathrm{~V}\right),(\mathrm{E} 1, \mathrm{~h}, \mathrm{VI}),\left(\mathrm{E} 2, \mathrm{j}_{1}, \mathrm{X}\right),\left(\mathrm{E} 3, \mathrm{k}_{3}\right.$, $X V),\left(F, i_{1}, V I\right),\left(G, j_{2}, X I\right),\left(H, e_{2}, X V I\right)$, (I, f, VIII), (J, e e, XII), (K, e e XX), (L, $c_{2}$, $\mathrm{XX}), \quad\left(\mathrm{M}, \mathrm{c}_{1}, \mathrm{XIV}\right), \quad\left(\mathrm{N}, \mathrm{d}_{3}, \mathrm{XXIII}\right), \quad\left(\mathrm{O}, \mathrm{d}_{5}\right.$, $\mathrm{XXI}),\left(\mathrm{P} 1, \mathrm{e}_{6}, \mathrm{XXII}\right) ，\left(\mathrm{P} 2, \mathrm{e}_{1}, \mathrm{XXIV}\right)$ はそれ ぞれ同一の運動終板の集団を異なった 断面で見て いることが知られた。また各群は著者等 ${ }^{25)}$ が咬筋
組織の筋線維構築所見から区画した各区画に 1 群 宛存在していることも明らかになった。なお運動 終板は単一筋線維に 1 個づつ存在し, ほぼ中央 $1 / 3$ の部分に限局していることも知られた。従って， ラットの咬筋はタイプ 1 筋線維の みから構成され るタイプI 筋に分類されることが判明した。Karl$\operatorname{sen}^{24)}$ はラットの咬筋のパラフィン切片や分離筋 


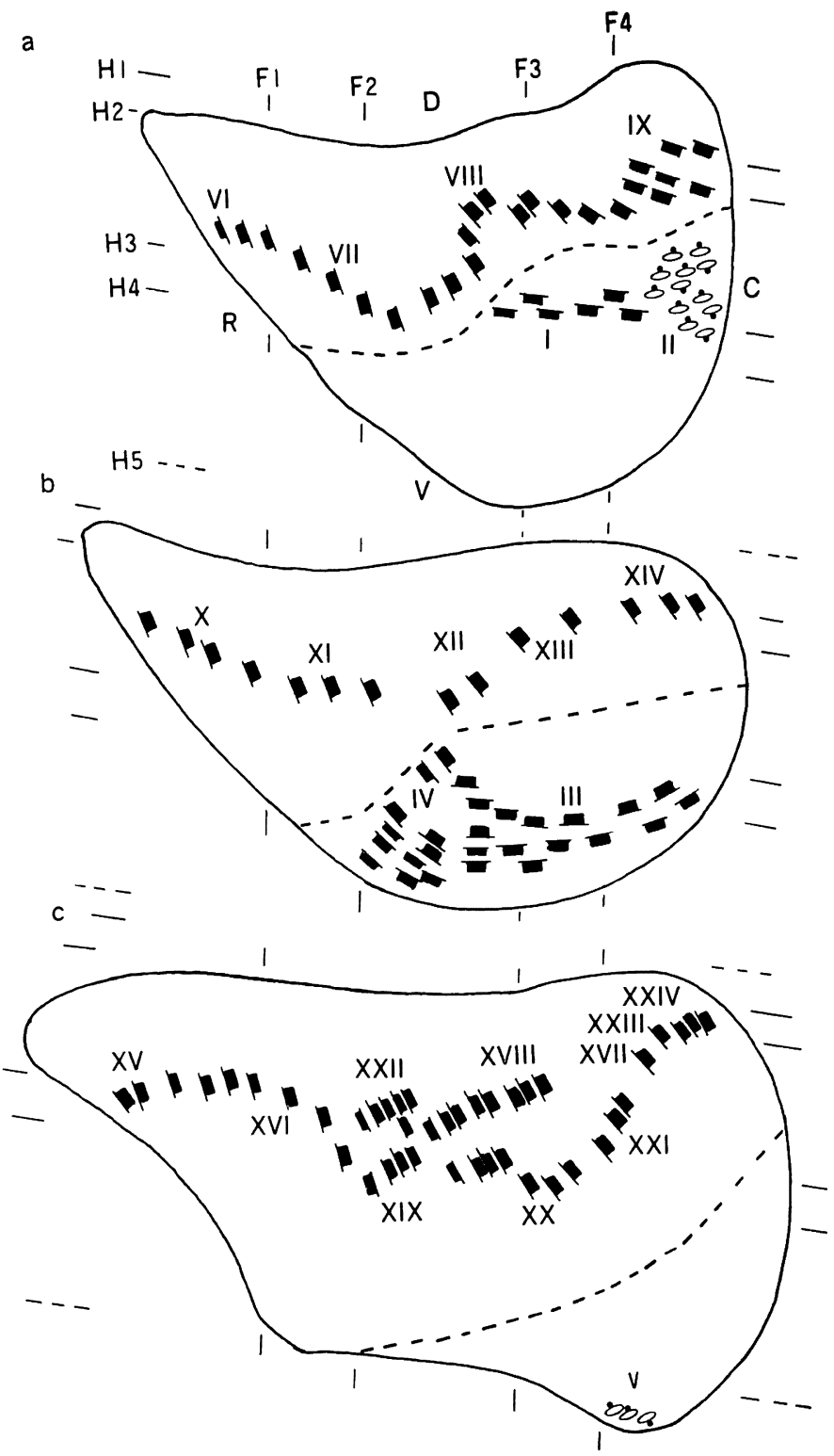

Fig. 5a-c. Distribution of motor endplates in the rat masseter. Parasagittal sections of the masseter viewed from the lateral surface. Sections at a; level S1; b; level S2; c ; level S3.

線維について運動終板の存在様式を検討して，大 部分の線維はタイプ1であるが，ごくまれにタイ プ 2 が存在することを報告している。しかし，著 者等はそのような像を見出すことはできなかっ た。

次に, 器官としての 1 個の筋内における運
動終板の 分布状態を検討すると， English \& Letbetter ${ }^{191}$ はネコの腓腹筋の外側頭と足底筋で, Galvas \& Gonyea ${ }^{20)}$ はネコの橈側手根屈筋で, 運動終板が筋の起始一停止方向にほぼ並走する 狭 い帯状域に分布していることを報告している。ま たラットの上斜笳 (Kaczmarski ${ }^{14)} ;$ Pachter $^{18)}$ ) 
やハタネズミやマウスの外側直筋 (Kaczmarski ${ }^{14}$ ) で，大部分の運動終板は起始部から停止部へかけ ての中央部で筋の走行にほぼ直交する帯状域に分 布しているが，一部のものはそれ以外の場所に分 散していることを報告し， Mayr, et al. ${ }^{21}$ はネコ の外眼筋で，運動終板が筋の起始部から停止部の 間で筋線維の走行に直交する 数個の直線状の帯状 域に分布することを, Herring, et al. ${ }^{23)}$ はブタの 咬筋で 運動終板が 腱膜間の中央部の狭い帯状域 に分布することを報告している。また Rossi \& Cortesina ${ }^{29)}$ はヒトの声帯筋や外側輪状披裂筋之 輪状甲状筋で, Repciuc \& Timus ${ }^{221}$ はラットの外 肛門括約筋や眼輪筋で, 運動終板が散在性に存在 していることを指摘している。これらの所見に反 して，著者等のラットの咬筋では運動終板が集団 （群）をなしながら筋の種々な部域に広く分布して いた。このことは著者等 ${ }^{25}$ が既報したようにラッ 卜咬筋の筋線維構築が複雑なことによるものであ る。

\section{結論}

成熟雄ウィスター系ラット咬筋の運動終板の 分 布状態をアセチルコリンエステラーゼ検出法であ る Beermann \& Cassens 法によって組織化学的 に検討して下記の所見を得た。

1. 紡鍾外筋線維における運動終板は 浅層筋, 深層筋ともに筋の種々な部位に集団をなして存在 していた。

2. それらの分布域は，著者等が既報した咬筋 組織の筋線維区画に一致していた。

3. いずれの運動終板の形態も terminaison en plaque 型であり, 単一筋線維のほぼ中央 $1 / 3$ 部 位に 1 個づつ存在していた。また 1 個の運動終板 には，1本の運動神経終末が見出された。

謝辞：稿を終えるにあたり，終始御懇篤な御指導と御 校閲を戴いた徳岛大学医学部第 1 解剖学講座山田正興 教授に深謝いたします。

抄録：ラット咬管における運動終板の分布状態を検討するために，三方向（前頭・水平・準矢状）の連続 切片を作製し, acetylcholinesterase 検出法である Beermann \& Cassens 法 (1976) を使用して組織化学的 に検討した。紡錘外筋線維における運動終板は浅層筋，深層筋ともに筋の種々な部位に集団をなして存在し ており，集団の分布域は，著者等が既報した咬筋組織の笳線維区画（Matsumoto \& Katsura, 1985）に一致 していた。またいずれの運動終板の形態も terminaison en plaque 型であり, 単一筋線維のほぼ中央 $1 / 3$ の部 位に 1 個つつ存在し，1 個の運動終板には 1 本の運動神経終末が認められた。

\section{文献}

1) Coërs, C. : Structure and organization of the myoneural junction. Int. Rev. Cytol. 22 : 239-267, 1967.

2) Cole, W. V.: Motor endings in the striated muscle of vertebrates. J. Comp. Neurol. $102: 671-715,1955$.

3) Couteaux, R.: Localization of cholinesterases at neuromuscular junctions. Int. Rev. Cytol. 4 : 335-375, 1955.

4) Couteaux, R.: motor end plate structure. In: The Structure and Function of Muscle. (Bourne, G.H. ed.), 2 nd. edn., Vol. II, pp. 483-530, Academic Press, New York \& London, 1973.

5) Tiegs, O. W. : Innervation of voluntary muscle. Physiol. Rev. 33 : 90-144, 1953.

6) Yamada, M. O.: Architecture in Histology. (Yamada, M. O. ed.), pp. 98-101,
Hirokawa Publish. Co., Tokyo, 1985.

7) Barker, D., Stacey, M. J. and Adal, M. N. : Fusimotor innervation in the cat. Philos. Trans. Soc. Lond. [Biol]. 258 : 315-346, 1970.

8) Bennett, M. R. and Pettigrew, A. G.: The formation of synapses in striated muscle during development. J. Physiol. 241 : 515-545, 1974.

9) Bennett, M. R. and Pettigrew, A. G.: The formation of synapses in reinnervated and cross-reinnervated striated muscle during development. J. Physiol. 241 : 547-573, 1974.

10) Christensen, E.: Topography of terminal motor innervation in striated muscles from stillborn infants. Am. J. Phys. Med. 38 : 6578, 1959.

11) Coërs, C.: Structural organization of the motor nerve endings in mammalian muscle spindles and other striated muscle fibers. Am. J. Phys. Med. 38 : 166-175, 1959. 
12) Diamond, J. and Miledi, R.: A study of foetal and new-born rat muscle fibres. J. Physiol. 162 : 393-408, 1962.

13) Ginsborg, B. L. and Mackay, B. : A histochemical demonstration of two types of motor innervation in avian skeletal muscle. Bibl. Anat. 2 : 174-181, 1961.

14) Kaczmarski, F.: Motor end-plates in the extraocular muscles of small mammals. Acta. Anat. 89 : 372-386, 1974.

15) Brown, M. C., Jansen, J. K. S. and van Essen, D. : Polyneuronal innervation of skeletal muscle in new-born rats and its elimination during maturation. J. Physiol. 261 : 387-422, 1976.

16) Hess, A. : Structural differences of fast and slow extrafusal muscle fibres and their nerve endings in chickens. J. Physiol. $157: 221-$ 231, 1961.

17) Mackay, B. and Peters, A.: Terminal innervation of segmental muscle fibres. Bibl. Anat. 2 : 182-193, 1961.

18) Pachter, B. R. : Rat extraocular muscle. 1. Three dimensional cytoarchitecture, component fibre populations and innervation. J. Anat. 137 : 143-159, 1983.

19) English, A. W . and Letbetter, W. D. : Anatomy and innervation patterns of cat lateral gastrocnemius and plantaris muscles. Am. J. Anat. $164: 67-77,1982$.

20) Galvas, P. E. and Gonyea, W. J. : Motorend-plate and nerve distribution in a histochemically compartmentalized pennate muscle in the cat. Am. J. Anat. $159: 147-156$, 1980.

21) Mayr, R., Gottschall, J., Gruber, H. and Neuhuber, W.: Internal structure of cat extraocular muscle. Anat. Embryol. 148 : 2534, 1975.

22) Repciuc, E. und Timus, M.: Die Synaptoarchitektonik des Muskels als Synchronapparat für die Muskelkontraktion. Z.Mikrosk. Anat. Forsch., Leipzig 94(3) : 545$555,1980$.

23) Herring, S. W., Grimm, A. F. and Grimm, B. R.: Functional heterogeneity in a multipinnate muscle. Am J. Anat. 154:563576, 1979.

24) Karlsen, K.: The location of motor end plates and the distribution and histological structure of muscle spindles in jaw muscles of the rat. Acta Odontol. Scand. 23 : 521547, 1965.

25) Matsumoto, H. and Katsura, S. : Multiple compartmentalization in the fiber architecture of rat masseter muscle. Acta Anat. Nippon. 60 : 90-98, 1985.

26) Beermann, D. H. and Cassens, R.G.: A combined silver and acetylcholinesterase method for staining intramuscular innervation. Stain Technol. 51 : 173-177, 1976.

27) Pearson, J. and Sabarra, A : A method for obtaining longitudinal cryostat sections of living muscle without contraction artifacts. Stain Technol. 49 : 143-146, 1974.

28) Weijs, W. A.: Morphology of the muscle of mastication in the albino rat, Rattus norvegicus (Berkenhout, 1769). Acta Morphol. Neerl. Scand. $11: 321-340,1973$.

29) Rossi, G. and Cortesina, G. : Morphological study of the laryngeal muscles in man. Insertions and courses of the muscle fibres, motor end-plates and proprioceptors. Acta Oto-laryngol. 59 : 575-592, 1965. 